\title{
INFLUÊNCIA DE PROCESSOS NATURAIS E TECNOGÊNICOS NA QUALIDADE DE ÁGUAS SUPERFICIAIS DE BLUMENAU-SC
}

Claudete Massuchin Percebon*

\author{
DISSERTAÇÃO DE MESTRADO - Programa de Pós-Graduação em Geologia - UFPR \\ DATA DE DEFESA: 07 ago. 2003
}

Esse é um estudo sobre a qualidade das águas superficiais de Blumenau - SC desenvolvido dentro de um programa de amostragens e análises que se estendeu por 24 meses, entre junho e 2000 a agosto de 2002. Fazem parte dessa avaliação os principais rios desse Município, a saber: o trecho do Itajaí-Açú, que divide a cidade e seus tributários. Na sua margem direita, o Garcia e o da Velha; e em sua margem esquerda: o do Testo, Itoupava e Fortaleza. Foram avaliados os resultados de 15 parâmetros físico-químicos diferentes, analisados nas águas destes rios. Fez-se o levantamento de informações da microrregião, como condições climáticas, topográficas, hidrográficas, geológicas, geomorfológicas, de uso do solo, do potencial poluidor das atividades econômicas locais, pedológicas e agropecuárias, entre outras. Foi confrontada a resposta de cada rio, segundo o resultado da qualidade de suas águas, aos fatores ambientais locais, esse foi um dos objetivos do presente estudo. O uso atual e futuro dessas águas superficiais, correspondentes à rede potamográfica estudada, seja para abastecimento público, seja com fi- nalidades turísticas ou de preservação ambiental, foi a justificativa para o estudo. Como principais conclusões desse estudo tem-se: a temperatura se mostrou um parâmetro de controle muito importante na avaliação da qualidade das águas superficiais; a condutividade foi o parâmetro mais fiel à qualidade das águas; a presença de mata ciliar nos rios e cobertura vegetal nas microbacias estudadas se mostraram como fatores positivos na qualidade das águas; a chuva evidenciou arrastar nutrientes para os rios em áreas mais expostas; o substrato drenado apresentou significativa correlação com a presença de cor, baixo pH e sólidos totais em diferentes pontos estudados; a correlação entre os parâmetros é maior para as águas de melhor qualidade; 0 método do IQA simplificado desenvolvido permitiu analisar a qualidade dos rios estudados. A metodologia desenvolvida neste diagnóstico, os mapas elaborados, as informações compiladas e as conclusões aqui apontadas poderão ser úteis nos trabalhos de monitoramento e preservação da qualidade dos rios da área, ou servirem de apoio a outras pesquisas ou estudos correlatos desenvolvidos na região.

E-mail: conseng@terra.com.br 